\title{
1,25-Dihydroxyvitamin D Stimulation Test for Osteoblast Function in Normal and Osteoporotic Postmenopausal Women
}

Ralph J. Duda, Jr., Rajiv Kumar, Karen I. Nelson, Alan R. Zinsmeister, Kenneth G. Mann, and B. Lawrence Riggs

Endocrine Research Unit and the Section of Medical Research Statistics, Mayo Clinic and Mayo Foundation, Rochester, Minnesota 55905; and the Department of Biochemistry, University of Vermont, Burlington, Vermont 05405

\begin{abstract}
The cause of bone loss in postmenopausal osteoporosis-decreased bone formation or increased bone resorption-is controversial. Synthesis of bone-Gla protein (BGP), a specific osteoblast product, is stimulated by 1,25-dihydroxyvitamin $D_{3}$ $\left[1,25(\mathrm{OH})_{2} \mathrm{D}\right]$ in vitro. Thus, increases in serum BGP levels during $1,25(\mathrm{OH})_{2} \mathrm{D}$ administration might provide a useful dynamic index of osteoblast function. We compared 14 postmenopausal osteoporotic women with 12 age-matched postmenopausal normal women before and during $6 \mathrm{~d}$ of $1,25(\mathrm{OH})_{2} \mathrm{D}$ administration $(2.0 \mu \mathrm{g} / \mathrm{d})$. Serum BGP levels were similar at baseline and increased during treatment in both groups $(P<0.001)$. However, trend analysis showed a greater $(P<0.01)$ increase in the osteoporotic women. These data do not support the hypothesis that defective osteoblast function is the major cause of bone loss in postmenopausal osteoporosis.
\end{abstract}

\section{Introduction}

The mechanism of bone loss in postmenopausal osteoporosis is controversial. Data have been reported supporting increased bone resorption or decreased bone formation or a combination of both processes. Combined kinetic and calcium balance data strongly suggest that overall bone turnover increases after menopause but resorption increases more than formation (1). Most radiocalcium kinetic studies have found normal accretion rates in postmenopausal osteoporosis despite decreased bone mass (2); however, Reeve et al. (3) reported that, among 21 patients with idiopathic osteoporosis, there was an inverse correlation between negative calcium balance and rates of bone accretion (assessed by long-term retention of ${ }^{85} \mathrm{Sr}$ ). Jowsey (4) and Nordin et al. (5) found that patients with postmenopausal osteoporosis had significant increases in resorption surfaces in iliac crest, and Wu et al. (6) reported an increase in the derived value for resorption rate in the rib. Bone histomorphometric studies using tetracycline double labeling have found high, normal, or low rates of bone turnover in iliac crest biopsy samples (7-9). Moreover, Darby and Meunier (10) reported decreased mean wall thickness of trabecular bone packets in iliac crest biopsy samples from women with postmenopausal osteoporosis, which suggests a decrease in bone formation at the cellular level.

Address reprint requests to Dr. Riggs, Endocrine Research Unit, Mayo Clinic, 200 First St. S.W., Rochester, MN 55905.

Received for publication 3 September 1986 and in revised form 11 December 1986.

J. Clin. Invest.

(C) The American Society for Clinical Investigation, Inc.

0021-9738/87/04/1249/05 $\$ 1.00$

Volume 79, April 1987, 1249-1253
An alternative way to study this problem is to measure bonespecific biochemical markers for bone turnover. Bone-Gla protein (BGP), ${ }^{1}$ also called "osteocalcin," a 49-residue peptide containing three residues of the vitamin $\mathrm{K}$-dependent amino acid $\gamma$-carboxyglutamic acid $(11,12)$, is a unique osteoblast product $(13,14)$. Radioimmunoassay of BGP in plasma has been found to be a sensitive test for bone turnover in patients with various metabolic bone diseases (15). In postmenopausal osteoporosis, serum BGP has been reported to be increased $(15,16)$ or normal $(17,18)$.

In contrast to many metabolic bone diseases, in osteoporosis the mean levels of bone turnover do not deviate greatly from normal, and there is a large overlap of individual values (7-9). We reasoned that a stimulation test for an osteoblast product might provide greater discrimination between normal and osteoporotic subjects than would be possible with static measurements of circulating levels. Osteoblasts contain receptors of the active vitamin $\mathrm{D}$ metabolite 1,25-dihydroxyvitamin $\mathrm{D}$ $\left[1,25(\mathrm{OH})_{2} \mathrm{D}\right](19)$, and BGP synthesis by osteoblast-like cells in vitro is stimulated by $1,25(\mathrm{OH})_{2} \mathrm{D}(20)$. Increases in serum BGP after $1,25(\mathrm{OH})_{2} \mathrm{D}$ treatment have been described by Gundberg et al. (21) in inherited rickets and by Pak et al. (22) in postmenopausal osteoporosis. Thus, if the hypothesis that postmenopausal osteoporosis is mainly caused by osteoblast atrophy is correct, the increases in serum BGP during $1,25(\mathrm{OH})_{2} \mathrm{D}$ administration should be less in osteoporotic than in nonosteoporotic postmenopausal women.

\section{Methods}

Subjects. The protocol for this study was reviewed and approved by the Mayo Institutional Review Board. All subjects gave their informed consent.

We studied 12 postmenopausal normal women and 14 postmenopausal women with osteoporosis; their mean $( \pm S E)$ ages were $64 \pm 2$ and $64 \pm 2 \mathrm{yr}$, respectively. All subjects were ambulatory. None was taking a drug known to affect calcium metabolism, had any evident disease known to be associated with bone disease, or abnormal hepatic function. All normal subjects had bone density values, assessed by dual-photon absorptiometry (23), that were within the age-adjusted normal range, and no vertebral fractures were seen on radiographs of the lumbar and thoracic spinal column. Patients with postmenopausal osteoporosis had one or more vertebral compression fractures, and lumbar spine densitometry gave values below the fracture threshold (23). None of the osteoporotic patients was receiving treatment for osteoporosis.

The patients were studied for $7 \mathrm{~d}$ in a metabolic ward. After a baseline day (day 0), the subjects received $1,25(\mathrm{OH})_{2} \mathrm{D}_{3}$ (Rocaltrol; Roche Laboratories, Nutley, $\mathrm{NJ})$ in a dosage of $0.5 \mu \mathrm{g}$ four times daily $(2.0 \mu \mathrm{g} / \mathrm{d})$ during the subsequent $6 \mathrm{~d}$ (days 1 through 6). Fasting-state blood samples were obtained at $0800 \mathrm{~h}$ for determinations of serum levels of BGP,

1. Abbreviations used in this paper: BGP, bone-Gla protein; GF, glomerular filtration; $1,25(\mathrm{OH})_{2} \mathrm{D}, 1,25$-hydroxyvitamin $\mathrm{D}$. 
Table I. Descriptive Characteristics of Experimental Subjects *

\begin{tabular}{lccl}
\hline Variable & $\begin{array}{c}\text { Postmenopausal } \\
\text { normal women }\end{array}$ & $\begin{array}{l}\text { Postmenopausal } \\
\text { osteoporotic women }\end{array}$ & $P$ \\
\hline Age $(\mathrm{yr})$ & $64 \pm 7$ & $64 \pm 8$ & $\mathrm{NS}$ \\
Height $(\mathrm{cm})$ & $163 \pm 6$ & $157 \pm 7$ & $\mathrm{NS}$ \\
Weight $(\mathrm{kg})$ & $68 \pm 14$ & $57 \pm 12$ & $<0.05$ \\
Surface area $\left(\mathrm{m}^{2}\right)$ & $1.73 \pm 0.16$ & $1.56 \pm 0.16$ & $<0.05$ \\
GFR $\left(\mathrm{ml} / \mathrm{min}\right.$ per $\left.1.73 \mathrm{~m}^{2}\right)$ & $90 \pm 14$ & $82 \pm 20$ & $\mathrm{NS}$ \\
& & & \\
\hline
\end{tabular}

* Data are given as mean $\pm \mathrm{SD}$.

calcium, alkaline phosphatase, and $1,25(\mathrm{OH})_{2} \mathrm{D}$. Daily urine samples were collected for determinations of calcium and hydroxyproline. Glomerular filtration rate (GFR) was assessed by creatinine clearance.

Basal levels of serum variables were computed by averaging values at the beginning and end of day 0 (immediately before $1,25(\mathrm{OH})_{2} \mathrm{D}$ treatment began). During $1,25(\mathrm{OH})_{2} \mathrm{D}$ treatment, all measurements were made on daily samples except for creatine clearance, which was measured at day 6 , and serum vitamin $\mathrm{D}$ metabolites, which were measured on pooled serum from days 5 and 6 .

Laboratory methods. Serum BGP was measured as described (24). The assay uses antiserum (R-102M; at a final dilution of $1: 20,000)$ raised in rabbits against bovine BGP and homogeneous bovine BGP for standard and tracer. Antibody-bound and free ${ }^{125}$ I-labeled BGP are separated by the double-antibody method. Both the intraassay and interassay variations of the assay typically were $<10 \%$. The sensitivity of the assay is $0.1 \mathrm{ng}$ of bovine BGP per tube, and the concentration of BGP can be measured in $>99 \%$ of normal subjects. Previous studies have shown that purified bovine BGP and human BGP displace BGP tracer from antibody with equal effectiveness. We verified that the presence of BGP in human serum causes the displacement of tracer from our antibody by demonstrating that standard curves obtained with bovine BGP and normal human serum samples were strictly parallel.
Serum and urine calcium were measured by atomic absorption spectrometry. Serum alkaline phosphatase was measured spectrophotometrically with $p$-nitrophenylphosphate substrate (Sigma Chemical Co., St. Louis, MO). Determinations of total alkaline phosphatase were performed in duplicate on all samples; the coefficient of variation was $<10 \%$. Serum and urine creatinine were measured by standard automated techniques. Urine hydroxyproline was measured by the method of Kivirikko et al. (25). Serum 25-hydroxyvitamin D was measured by the method of Eisman et al. (26). Serum $1,25(\mathrm{OH})_{2} \mathrm{D}$ was measured by a modification of the method of Eisman et al. (27) as described by Kumar et al. (28).

Data analysis. Baseline variables were compared by two-tailed $t$ tests. During $1,25(\mathrm{OH})_{2} \mathrm{D}$ administration, logarithmic transformation of response variables was used when necessary to stabilize variances between groups and across time. Changes in serum BGP and other response variables over time were assessed by growth curve analysis (29). The growth curve analysis summarizes the values for each response variable measured on days 1 through 6 for each subject in terms of trends over time. These trends were represented in this case by mean, linear, and quadratic coefficients. Thus, instead of six values for each response variable (e.g., BGP on days 1 to 6), each subject's response on a particular variable was summarized in terms of three trend coefficients. These three coefficients were then compared between groups using one-way multivariate analysis of covariance. This analysis simultaneously compared the three trends after adjusting for differences between groups in the covariates. The covariates in this analysis were weight, body surface area, GFR, baseline serum level of the response variable, and increment in serum level of $1,25(\mathrm{OH})_{2} \mathrm{D}$ between baseline and day 6 . The ability of the three coefficients to adequately summarize the six daily values for individual subjects was assessed by testing whether the three trends were sufficient relative to requiring higher degree terms (29). This test failed to detect departures from the assumed (three trend) model.

\section{Results}

Descriptive characteristics of the experimental subjects are given in Table I. Baseline and response variables (summarized as 3-d

Table II. Serum Variables at Baseline and during $1,25(\mathrm{OH})_{2} \mathrm{D}$ Administration

\begin{tabular}{|c|c|c|c|c|c|c|c|}
\hline \multirow[b]{2}{*}{ Variable } & \multirow[b]{2}{*}{ Day* } & \multicolumn{2}{|c|}{$\begin{array}{l}\text { Postmenopausal women } \\
\text { (mean } \pm \text { SE) }\end{array}$} & \multicolumn{4}{|l|}{$P^{\ddagger}$} \\
\hline & & Normal & Osteoporotic & $\mathbf{A}$ & B & C & D \\
\hline \multirow[t]{3}{*}{$\mathrm{BGP}(n g / m l)$} & BL & $8.7 \pm 0.6$ & $8.7 \pm 0.4$ & NS & $<0.001$ & $<0.001$ & $<0.05$ \\
\hline & $1-3$ & $9.9 \pm 0.6$ & $10.2 \pm 0.4$ & & & & \\
\hline & $4-6$ & $10.0 \pm 0.7$ & $11.0 \pm 0.4$ & & & & \\
\hline \multirow[t]{3}{*}{ Alkaline phosphatase (U/liter) } & BL & $100 \pm 5$ & $114 \pm 9$ & $\mathbf{N S}^{\S}$ & $\mathrm{NS}^{\S}$ & $\mathrm{NS}^{\S}$ & $\mathrm{NS}^{\S}$ \\
\hline & $1-3$ & $100 \pm 6$ & $112 \pm 8$ & & & & \\
\hline & $4-6$ & $98 \pm 5$ & $114 \pm 8$ & & & & \\
\hline \multirow[t]{3}{*}{ Calcium $(m g / d l)$} & BL & $9.6 \pm 0.1$ & $9.5 \pm 0.1$ & NS & NS & NS & NS \\
\hline & $1-3$ & $9.7 \pm 0.1$ & $9.6 \pm 0.1$ & & & & \\
\hline & $4-6$ & $9.7 \pm 0.1$ & $9.7 \pm 0.1$ & & & & \\
\hline \multirow[t]{2}{*}{ 25-Hydroxyvitamin D $(\mathrm{ng} / \mathrm{ml})$} & BL & $20.5 \pm 3.0$ & $20.3 \pm 2.4$ & NS & NS & NS & $\mathbf{N S}^{\prime \prime}$ \\
\hline & $5-6$ & $25.2 \pm 2.7$ & $21.6 \pm 2.0$ & & & & \\
\hline \multirow[t]{2}{*}{$1,25(\mathrm{OH})_{2} \mathrm{D}(\mathrm{pg} / \mathrm{ml})$} & BL & $42 \pm 4$ & $42 \pm 6$ & NS & $<0.05$ & $<0.001$ & $\mathbf{N S}^{\prime \prime}$ \\
\hline & $5-6$ & $61 \pm 7$ & $76 \pm 10$ & & & & \\
\hline
\end{tabular}

\footnotetext{
* Day of study: BL, baseline; 1-3, mean of values for first $3 \mathrm{~d}$ of $1,25(\mathrm{OH})_{2} \mathrm{D}$ administration; 4-6, mean of final 3 d; 5-6, days 5-6. ${ }^{\ddagger} \mathrm{A}$, For difference between groups in baseline values; $B$, for difference between baseline value and mean value during $1,25(\mathrm{OH})_{2} \mathrm{D}$ administration in the normal postmenopausal women; $\mathrm{C}$, for difference between baseline value and mean value during $1,25(\mathrm{OH})_{2} \mathrm{D}$ administration in the osteoporotic postmenopausal women; $\mathrm{D}$, for difference in trends between groups during $1,25(\mathrm{OH})_{2} \mathrm{D}$ administration. ${ }^{8}$ Logarithmic transformation used for analysis. "Difference assessed by paired $t$ test because multiple values were not available.
} 


\begin{tabular}{|c|c|c|c|c|c|c|c|}
\hline \multirow[b]{2}{*}{ Variable } & \multirow[b]{2}{*}{ Day* } & \multicolumn{2}{|c|}{$\begin{array}{l}\text { Postmenopausal women } \\
\text { (mean } \pm \text { SE) }\end{array}$} & \multicolumn{4}{|l|}{$P^{\ddagger}$} \\
\hline & & Normal & Osteoporotic & A & B & C & $\mathbf{D}$ \\
\hline \multirow[t]{3}{*}{ Hydroxyproline $(\mu g / 24 h$ per $100 \mathrm{ml} \mathrm{GF})$} & BL & $19 \pm 2$ & $25 \pm 3$ & NS & $<0.01$ & $<0.05$ & NS \\
\hline & $1-3$ & $22 \pm 2$ & $26 \pm 2$ & & & & \\
\hline & $4-6$ & $24 \pm 2$ & $28 \pm 2$ & & & & \\
\hline \multirow[t]{3}{*}{ Calcium $(m g / 24 h)$} & BL & $97 \pm 11$ & $84 \pm 9$ & $\mathrm{NS}^{\S}$ & $<0.001^{8}$ & $<0.001^{8}$ & $\mathrm{NS}^{8}$ \\
\hline & $1-3$ & $145 \pm 10$ & $171 \pm 15$ & & & & \\
\hline & $4-6$ & $200 \pm 11$ & $232 \pm 18$ & & & & \\
\hline \multirow[t]{2}{*}{ Creatinine clearance $\left(\mathrm{ml} / \mathrm{min}\right.$ per $\left.1.73 \mathrm{~m}^{2}\right)$} & BL & $90 \pm 4$ & $82 \pm 5$ & NS & NS & NS & NS \\
\hline & 6 & $85 \pm 4$ & $91 \pm 5$ & & & & \\
\hline
\end{tabular}

\begin{abstract}
* Day of study: BL, baseline; 1-3, mean of values for first $3 \mathrm{~d}$ of $1,25(\mathrm{OH})_{2} \mathrm{D}$ administration; 4-6, mean of final $3 \mathrm{~d}$. ${ }^{\ddagger} \mathrm{A}$, For difference between groups in baseline values; $\mathrm{B}$, for difference between baseline value and mean value during $1,25(\mathrm{OH})_{2} \mathrm{D}$ administration in the normal postmenopausal women; $\mathrm{C}$, for difference between baseline value and mean value during $1,25(\mathrm{OH})_{2} \mathrm{D}$ administration in the osteoporotic postmenopausal women; $\mathrm{D}$, for difference in trends between groups during $1,25(\mathrm{OH})_{2} \mathrm{D}$ administration. ${ }^{8}$ Logarithmic transformation used for analysis.
\end{abstract}

pooled means) are given in Table II for serum measurements and in Table III for urine measurements. The increase over baseline of daily values for serum BGP is shown in Fig. 1. The relationship between the increase in levels of serum $1,25(\mathrm{OH})_{2} \mathrm{D}$ and the increase in levels of serum BGP for individual subjects is given in Fig. 2. Even adjusting for differences in serum $1,25(\mathrm{OH})_{2} \mathrm{D}$, the increase in serum BGP was greater in the osteoporotic subjects. There were no differences between groups in any variable at baseline. During $1,25(\mathrm{OH})_{2} \mathrm{D}$ stimulation, multivariate analysis of serum values of BGP showed a difference in trends $(P<0.01)$ between the normal and osteoporotic groups of postmenopausal women. This was mainly due to linear trends for the two groups with the osteoporotic group having a greater increase after adjustment for covariates $(P<0.05)$. There was no significant difference in the other response variables, including serum $1,25(\mathrm{OH})_{2} \mathrm{D}$, between the two groups.

\section{Discussion}

The mean basal value for serum BGP in this group of 14 osteoporotic women was only slightly less than we found in a previous study (16) involving 62 osteoporotic women. Thus, we believe that our study subjects were representative of patients with postmenopausal osteoporosis and did not contain an excessive proportion of patients with high bone turnover.

After $1,25(\mathrm{OH})_{2} \mathrm{D}$ administration, serum BGP increased in both the normal and osteoporotic groups. The most likely mechanism for this was increased synthesis of BGP by osteoblasts. There is strong evidence that, in the absence of renal failure, circulating BGP reflects bone formation, not bone resorption $(18,30-33)$. Although there was an increase in urinary hydroxyproline of $12-25 \%$ during $1,25(\mathrm{OH})_{2} \mathrm{D}_{3}$ administration, a small increase in bone resorption rate should not have increased serum BGP. Riggs et al. (34) induced an acute increase in bone resorption by a 24-h infusion of the synthetic 1-34 fragment of parathyroid hormone; despite an $80 \%$ increase in urinary hydroxyproline, serum BGP decreased significantly. Presumably BGP in bone matrix is degraded into fragments that are not recognized by our antiserum. The theoretic possibility that
$1,25(\mathrm{OH})_{2} \mathrm{D}$ administration decreased plasma clearance of BGP seems very unlikely.

The increase in serum BGP during $1,25(\mathrm{OH})_{2} \mathrm{D}$ administration was significantly greater in the osteoporotic than in the normal postmenopausal women. This difference remained statistically significant after adjustment for important covariates. This is strong evidence against the hypothesis that bone loss in postmenopausal osteoporosis results from osteoblast atrophy. If this hypothesis were correct, the stimulated response in the osteoporotic women should have been blunted, whereas the opposite was observed.

These findings differ from those reported on the basis of histomorphometric studies; the latter have shown that $\sim 30 \%$ of patients with postmenopausal osteoporosis have low turnover in trabecular bone in the iliac crest (7-9). This discrepancy cannot be resolved at present. It has been suggested that the low turnover state in postmenopausal osteoporotic patients may represent the end stage of a previous period of bone loss associated with higher turnover $(35,36)$. Because trabecular bone of the axial skeleton is more active metabolically, it is possible that it reaches this end stage before the predominately cortical bone in the remainder of the skeleton. If so, increased remodeling in cortical bone could account for the increased response to $1,25(\mathrm{OH})_{2} \mathrm{D}$ stimulation, which affects BGP synthesis by the entire skeleton. This

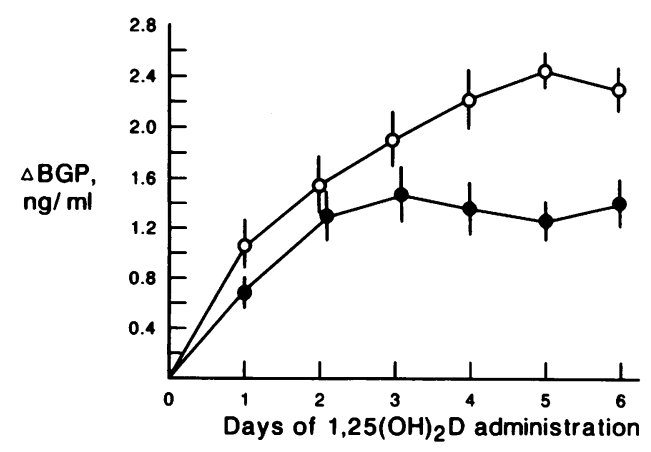

Figure 1. Incremental change in serum BGP (mean \pm SE) over baseline during $1,25(\mathrm{OH})_{2} \mathrm{D}$ administration in postmenopausal normal women (solid circles) and postmenopausal osteoporotic women (open circles). 


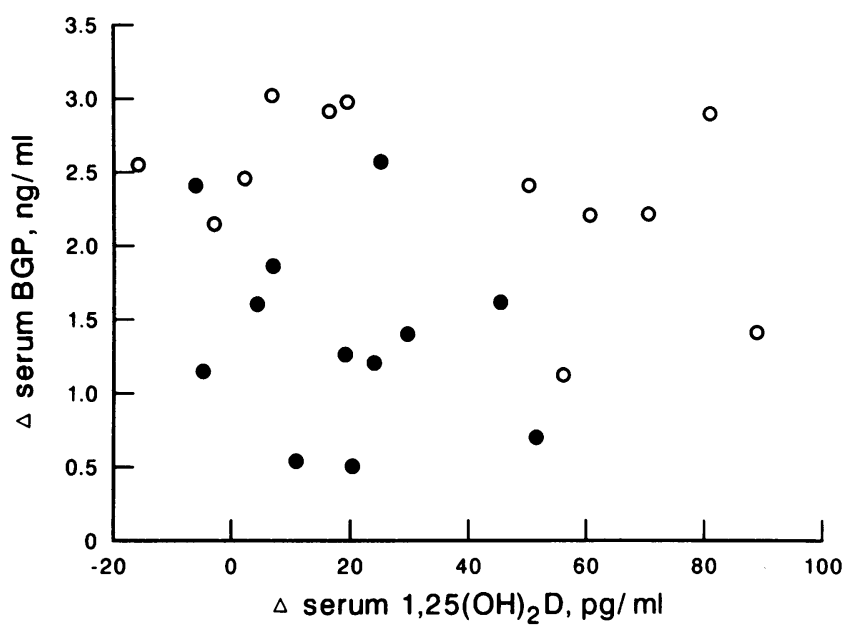

Figure 2. Relationship between incremental increase in levels of serum $1,25(\mathrm{OH})_{2} \mathrm{D}$ and corresponding increase in levels of serum BGP in postmenopausal normal women (solid circles) and postmenopausal osteoporotic women (open circles). Even when adjusting for differences in the level of serum $1,25(\mathrm{OH})_{2} \mathrm{D}$, the level of serum BGP is higher in the women with postmenopausal osteoporosis.

would offset the decreased bone remodeling in some osteoporotic patients that may be mainly confined to trabecular bone of the axial skeleton.

Serum BGP levels 'increased during $1,25(\mathrm{OH})_{2} \mathrm{D}$ administration, but serum alkaline phosphatase levels did not change. Although we cannot exclude offsetting changes in serum isoenzymes of alkaline phosphatase, this seems unlikely. The dissociated responses of these osteoblast products to $1,25(\mathrm{OH})_{2} \mathrm{D}$ administration suggests either that two populations of osteoblasts exist or that osteoblasts respond differently in various stages of maturation. Further studies will be needed to evaluate these possibilities.

Stimulation tests are commonly used to assess the reserve capacity of endocrine tissue and may give abnormal results even when basal levels of hormones are normal. The results we have obtained in this study encourage us to believe that this approach also may be useful in evaluating patients who have metabolic bone disorders. As more products specific for bone cells are found, and as the factors that regulate their synthesis are identified, stimulation tests for bone cell function should become more sophisticated.

\section{Acknowledgments}

This work was supported in part by National Institutes of Health grants AG-04875, DK-07147, and RR-00585.

\section{References}

1. Heaney, R. P., R. R. Recker, and P. D. Saville. 1978. Menopausal changes in bone remodeling. J. Lab. Clin. Med. 92:964-970.

2. Harris, W. H., and R. P. Heaney. 1969. Skeletal renewal and metabolic bone disease. N. Engl. J. Med. 280:193-202.

3. Reeve, J., J. R. Green, R. Hesp, and P. Hulme. 1982. Rates of new bone formation in patients with crush fracture osteoporosis. Clin. Sci. 63:153-160.
4. Jowsey, J. 1977. Metabolic Diseases of Bone. W. B. Saunders \& Co., Philadelphia. 256-295.

5. Nordin, B. E. C., J. Aaron, R. Speed, and R. G. Crilly. 1981. Bone formation and resorption as the determinants of trabecular bone volume in postmenopausal osteoporosis. Lancet. ii:277-279.

6. Wu, K., S. Jett, and H. M. Frost. 1967. Bone resorption rates in rib in physiological, senile, and postmenopausal osteoporoses. J. Lab. Clin. Med. 69:810-818.

7. Meunier, P. J., S. Sellami, D. Briancon, and C. Edouard. 1980. Histological heterogeneity of apparently idiopathic osteoporosis. In Osteoporosis: Recent Advances in Pathogenesis and Treatment. H. F. DeLuca, H. M. Frost, W. S. S. Jee, C. C. Johnston, Jr., and A. M. Parfitt, editors. University Park Press, Baltimore. 293-301.

8. Parfitt, A. M., C. Mathews, D. Rao, B. Frame, M. Kleerekoper, and A. R. Villaneuva. 1980. Impaired osteoblast function in metabolic bone disease. In Osteoporosis: Recent Advances in Pathogenesis and Treatment. H. F. DeLuca, H. M. Frost, W. S. S. Jee, C. C. Johnston, Jr., and A. M. Parfitt, editors. University Park Press, Baltimore. 321330.

9. Whyte, M. P., M. A. Bergfeld, W. A. Murphy, L. V. Avioli, and S. L. Teitelbaum. 1982. Postmenopausal osteoporosis: a heterogeneous disorder as assessed by histomorphometric analysis of iliac crest bone from untreated patients. Am. J. Med. 72:193-202.

10. Darby, A. J., and P. J. Meunier. 1981. Mean wall thickness and formation periods of trabecular bone packets in idiopathic osteoporosis. Calcif. Tissue Int. 33:199-204.

11. Hauschka, P. V., J. B. Lian, and P. M. Gallop. 1975. Direct identification of the calcium-binding amino acid, $\gamma$-carboxyglutamate, in mineralized tissue. Proc. Natl. Acad. Sci. USA. 72:3925-3929.

12. Price, P. A., A. S. Otsuka, J. W. Poser, J. Kristaponis, and N. Raman. 1976. Characterization of a $\gamma$-carboxyglutamic acid-containing protein from bone. Proc. Natl. Acad. Sci. USA. 73:1447-1451.

13. Price, P. 1983. Osteocalcin. In Bone and Mineral Research, Annual 1. W. A. Peck, editor. Excerpta Medica, Amsterdam, Oxford, Princeton. 157-190.

14. Beresford, J. N., J. A. Gallagher, J. W. Poser, and R. G. G. Russell. 1984. Production of osteocalcin by human bone cells in vitro. Effects of $1,25(\mathrm{OH})_{2} \mathrm{D}_{3}$, parathyroid hormone, and glucocorticoids. $\mathrm{Me}$ tab. Bone Dis. Relat. Res. 5:229-234.

15. Price, P. A., J. G. Parthemore, and L. J. Deftos. 1980. New biochemical marker for bone metabolism: measurements by radioimmunoassay of bone Gla-protein in the plasma of normal subjects and patients with bone disease. J. Clin. Invest. 66:878-883.

16. Delmas, P. D., H. W. Wahner, K. G. Mann, and B. L. Riggs. 1983. Assessment of bone turnover in postmenopausal osteoporosis by measurement of serum bone Gla-protein. J. Lab. Clin. Med. 102:470475.

17. Gundberg, C. M., J. B. Lian, P. M. Gallop, and J. J. Steinberg. 1983. Urinary $\gamma$-carboxyglutamic acid and serum osteocalcin as bone markers: studies in osteoporosis and Paget's disease. J. Clin. Endocrinol. Metab. 57:1221-1225.

18. Brown, J. P., P. D. Delmas, L. Malaval, C. Edouard, M. C. Chapuy, and P. J. Meunier. 1984. Serum bone gla-protein: a specific marker for bone formation in postmenopausal osteoporosis. Lancet. i: 1091-1093.

19. Chen, T. L., C. M. Cone, E. Morey-Holton, D. Feldman. 1983. $1 \alpha, 25$-Dihydroxyvitamin $D_{3}$ receptors in cultured rat osteoblast-like cells. Glucocorticoid treatment increases receptor content. J. Biol. Chem. 258: 4350-4355.

20. Price, P. A., and S. A. Baukol. 1980. 1,25-Dihydroxyvitamin $D_{3}$ increases synthesis of the vitamin K-dependent bone protein by osteosarcoma cells. J. Biol. Chem. 225:11660-11663.

21. Gundberg, C. M., D. E. C. Cole, J. B. Lian, T. M. Reade, and P. M. Gallop. 1983. Serum osteocalcin in the treatment of inherited rickets with 1,25-dihydroxyvitamin $\mathrm{D}_{3}$. J. Clin. Endocrinol. Metab. 56: 1063-1067. 
22. Zerwekh, J. E., K. Sakhaee, and C. Y. C. Pak. 1985. Short-term 1,25-dihydroxyvitamin $\mathrm{D}_{3}$ administration raises serum osteocalcin in patients with postmenopausal osteoporosis. J. Clin. Endocrinol. Metab. 60:615-617.

23. Riggs, B. L., H. W. Wahner, W. L. Dunn, R. B. Mazess, K. P. Offord, and L. J. Melton. 1981. Differential changes in bone mineral density of the appendicular and axial skeleton with aging. J. Clin. Invest. 67:328-335.

24. Delmas, P. D., D. Stenner, H. W. Wahner, K. G. Mann, and B. L. Riggs. 1983. Increases in serum bone $\gamma$-carboxyglutamic acid protein with aging in women. J. Clin. Invest. 71:1316-1321.

25. Kivirikko, K. I., O. Laitiner, and D. J. Prockop. 1967. Modification of a specific assay for hydroxyproline in urine. Anal. Biochem. 19:249-255.

26. Eisman, J. A., R. M. Shepard, and H. F. DeLuca. 1977. Determination of 25-hydroxyvitamin $D_{2}$ and 25-hydroxyvitamin $D_{3}$ in human plasma using high-pressure liquid chromatography. Anal. Biochem. 80: 298-305.

27. Eisman, J. A., A. J. Hamstra, B. E. Kream, and H. F. DeLuca. 1976. A sensitive, precise, and convenient method for determination of 1,25-dihydroxyvitamin D in human plasma. Arch. Biochem. Biophys. 176:235-243.

28. Kumar, R., W. R. Cohen, P. Silva, and F. H. Epstein. 1979. Elevated 1,25-dihydroxyvitamin D plasma levels in normal human pregnancy and lactation. J. Clin. Invest. 63:342-344.
29. Grizzle, J. E., and D. M. Allen. 1969. Analysis of growth and dose response curves. Biometrics. 25:337-381.

30. Price, P. A., and M. K. Williamson. 1981. Effects of warfarin on bone: studies on the vitamin K-dependent protein of rat bone. J. Biol. Chem. 256:12754-12759.

31. Delmas, P. D., L. Malaval, M. E. Arlot, and P. J. Meunier. 1985. Serum bone Gla-protein compared to bone histomorphometry in endocrine diseases. Bone. 6:339-341.

32. Charles, P., J. W. Poser, L. Mosekilde, and F. T. Jensen. 1985. Estimation of bone turnover evaluated by ${ }^{47} \mathrm{Ca}$-kinetics. Efficiency of serum bone gamma-carboxyglutamic acid-containing protein, serum alkaline phosphatase, and urinary hydroxyproline excretion. J. Clin. Invest. 76:2254-2258.

33. Gundberg, C. M., and R. S. Weinstein. 1986. Multiple immunoreactive forms of osteocalcin in uremic serum. J. Clin. Invest. 77: 1762-1767.

34. Riggs, B. L., K.-S. Tsai, and K. G. Mann. 1986. Effect of acute increases in bone matrix degradation on circulating levels of bone-Gla protein. J. Bone Min. Res. 1:539-542.

35. Kruse, H. P., and F. Kuhlencordt. 1980. Pathogenesis and natural course of primary osteoporosis. Lancet. i:280-282.

36. Parfitt, A. M., C. H. E. Mathews, A. R. Villanueva, M. Kleerekoper, B. Frame, and D. S. Rao. 1983. Relationships between surface, volume, and thickness of iliac trabecular bone in aging and in osteoporosis. J. Clin. Invest. 72:1396-1409. 